\title{
Expression Analysis of PKS13, FG08079.1 and PKS10 Genes in Fusarium graminearum and Fusarium culmorum
}

\author{
Emre Yörük 1, Elif Karlik 1, Aylin Gazdagli 1, Müyesser Kayis 1, Funda Kaya 1 , Gülruh Albayrak 2,* \\ ${ }^{1}$ Programme of Molecular Biology and Genetics, Institute of Science, Istanbul University, Istanbul, Turkey \\ ${ }^{2}$ Department of Molecular Biology and Genetics, Faculty of Science, Istanbul University, Istanbul, Turkey \\ ${ }^{*}$ Corresponding author: Gülruh Albayrak, Istanbul University, Faculty of Science, Department of Molecular Biology and Genetics 34134 Vezneciler,
Fatih/Istanbul, Turkey. Tel: +90-2124555700/15134, Fax: +90-2124555811, E-mail: gulruh@istanbul.edu.tr
}

Received: October 10, 2014; Revised: March 14, 2015; Accepted: April 19, 2015

Background: Identification and quantification of mycotoxins produced by Fusarium species are important in controlling fungal diseases.

Objectives: Potential of zearalenone, butenolide and fusarin $\mathrm{C}$ production was investigated in five Fusarium graminearum and five $F$. culmorum isolates at molecular level.

Materials and Methods: Presence of PKS13, FG08079.1 and PKS10 genes, associated with production of zearalenone, butenolide and fusarin $C$, respectively, were confirmed by PCR. In addition, expression levels of them together with housekeeping gene ( $\beta$-tubulin) were detected by real time PCR.

Results: PKS13 and FG08079.1 transcripts were determined in all isolates, while PKS10 specific primers failed to amplify any product, indicative of no expression. $\triangle \triangle \mathrm{CT}$ of $P K S 13$ was ranged between 1.79E-03-3.97E-03 and for FG08079.1 was between $0.25 \mathrm{E}-03$ and $6.02 \mathrm{E}-03$. The highest $P K S 13$ expressions were $3.86 \mathrm{E}-03$ in $F$. graminearum $\mathrm{F} 9$ and 3.97E-03 in F. culmorum F16. Maximum FG08079.1 expressions were calculated as $6.02 \mathrm{E}-03$ and 3.81E-03 in F. graminearum $2 \mathrm{~F}$ and F. culmorum $\mathrm{F} 2$, respectively.

Conclusions: We revealed that ten Fusarium isolates produced zearalenone and butenolide under culture conditions. However, fusarin $\mathrm{C}$ was not generated by them in these conditions.

Keywords: Butenolide; Fusarium culmorum; Fusarin C; Fusarium graminearum; Zearalenone

\section{Background}

Mycotoxins are fungal secondary metabolism's products with low-molecular weight. Fungi producing mycotoxins are well-defined at genera level (1). Fusarium is well known genus infecting considerable plant species especially small-grain cereals $(2,3)$. Fusarium graminearum and $F$. culmorum are common mycotoxin producers. Their mycotoxins can be divided into two classes as: (i) Major consisting of trichothecenes, fumonisins, zearalenones, and (ii) minor including beauvercin and enniatins, equisetin, fusarins, butenolide (4).

Both $F$. graminearum and $F$. culmorum have the ability to produce zearalenone (ZEN), butenolide (BUT) and fusarin C (FUS C) mycotoxins (4). ZEN is a nonsteroidal estrogenic endotoxin synthesized from gene cluster that of $25 \mathrm{~kb}$. Cluster consists of nine genes. PKS4 and PKS13 encoding two different polyketide synthases (PKS) are essential for ZEN production. Disruption of these genes resulted in loss of ZEN production $(5,6)$. BUT is a water-soluble endotoxin and produces by a gene cluster with eight genes on a contig, namely 1.324. Gene disruption and addback approaches indicated that $F G 08079.1$ gene in the cluster is essential for BUT production. According to sequence similarity, FG08079.1 appears to be a cytochrome P450 monooxygenase, while the function of other 7 genes remained elusive (7). FUS C is one of the fusarin stereoisomers. FUS C biosynthetic pathway is controlled by cluster of nine genes reported in $F$. fujikuroi. The fus 1 is essential in production and its product is a PKS. It was shown that PKS10 in F. graminearum was homologous to fus 1 of $F$. fujikuroi $(8,9)$.

Detection of mycotoxins within crops and their products is very important for human, animal and plant 
health. Several conventional methods are effectively used for determination of mycotoxins. High-performance liquid chromatography/mass spectrometry (HPLC/MS), gas chromatography-mass spectrometry (GC-MS), liquid chromatography with tandem mass spectrometry (LC-MS/MS) and enzyme linked immunosorbent assay (ELISA) are methods regularly being used for mycotoxin determination and sometimes quantification. However, these techniques are labour intensive, time consuming and expensive. Instead of using above direct methods in identification and determination of the presence of mycotoxins, one may evaluate the presence of genes involved in biosynthesis of such substances via PCR and further investigate their expression via Real-Time PCR (10).

\section{Objectives}

Expression of PKS13, FG08079.1 and PKS10, the key players of zearalenon, butenolide and fusarin $\mathrm{C}$ (FUS C) production, were analysed. It was aimed to determine mycotoxin production potential of $F$. graminearum and $F$. culmorum isolates and relative quantification of expression of the genes.

\section{Materials and Methods}

\subsection{Fungal Isolation and Culture}

F5, F8, F9, 1F, 2F, F2, F12, F15, F16 and F19 isolates was obtained from single-spore cultures (11). Isolates (Table 1) were kindly provided from Prof. Berna Tunali, at Samsun Ondokuz Mayis University, Plant Protection Department of Agriculture Faculty. Isolates were grown at $25^{\circ} \mathrm{C}$ on potato dextrose agar (PDA).

\subsection{Polymerase Chain Reaction}

Genomic DNA was extracted from $100 \mathrm{mg}$ of 7day-old fresh mycelium using CTAB method with minor modifications (12). Total RNA was extracted using Roche TriPure Reagent (Roche, Switzerland) that used for cDNAs synthesis using Roche cDNA synthesis kit (Roche, Switzerland) following to manufacturer's protocol.

UBC $85 \mathrm{~F} / \mathrm{R}$ (5'-ctccggatatgttgcgtcaa- $3^{\prime} / 5^{\prime}$-ggtaggtatccgacatggcaa-3') and OPT18F/R (5'-atggtgaactcgtcgtggc- $3^{\prime} / 5^{\prime}$-ccettcttacgccaatctcg- $3^{\prime}$ ) primer sets were used in amplification of SCAR85 marker specific for $F$. graminearum and SCAR2-35 for $F$. culmorum, respectively (13). PCR cycling and conditions were maintained as described by Schilling et al. (13) in a thermocycler (Bio-Rad-T100, USA).

ZENF/R (5' -ggtagcgataacgtggagga- $3^{\prime} / 5^{\prime}$-gactcaaaggtgctcggttc- $\left.3^{\prime}\right)$, BUTF/R (5' -tcattgaccgagctttctga$3^{\prime} / 5^{\prime}$-ctccatcgtgtcgtctctca- $\left.3^{\prime}\right)$ and FUSCF/R (5'-ttccccctgtacgattcaac- $3^{\prime} / 5^{\prime}$-tcattgaccgagctttctga- $\left.3^{\prime}\right)$ primers were used for amplification of PKS13 (Acc. no: AY495638.1), FG08079.1 (Acc. no: FG08079.1) and PKS10 (Acc. no: AY495635.1) genes, respectively. PCR mixing were carried out as previously described by Yörük and Albayrak (14). The thermal cycling conditions were applied as 40 cycles of $94^{\circ} \mathrm{C}$ for $1 \mathrm{~min}$, $55-57^{\circ} \mathrm{C}$ for $1 \mathrm{~min}$ and $72^{\circ} \mathrm{C}$ for $2 \mathrm{~min}$. Prior to cycling, PCR tubes were incubated at $95^{\circ} \mathrm{C}$ for $5 \mathrm{~min}$, and the cyclings were finished with at $72^{\circ} \mathrm{C}$ for $10 \mathrm{~min}$ Standard Taq DNA polymerase enzyme kit (Promega, USA) was used in each PCR sets.

\subsection{Real-Time PCR}

Real-time PCR assays were carried out in

\begin{tabular}{|c|c|c|c|c|c|c|}
\hline \multirow{2}{*}{ Isolate } & \multirow{2}{*}{ Location } & \multicolumn{3}{|c|}{$\Sigma \mathrm{Cp}$} & \multicolumn{2}{|c|}{$\Sigma \Delta \Delta \mathrm{CT}$} \\
\hline & & FG08079.1 & PKS13 & $\beta$-tubulin & FG08079.1 & PKS13 \\
\hline $\mathrm{F}^{*}$ & Sakarya & $32,18 \pm 1,14$ & $31,42 \pm 0,05$ & $22,93 \pm 0,34$ & 1,64E-03 & $2,79 \mathrm{E}-03$ \\
\hline F8* & Sakarya & $30,99 \pm 0,07$ & $31,52 \pm 0,59$ & $23,28 \pm 0,034$ & 4,78E-03 & $3,30 E-03$ \\
\hline $\mathrm{F}^{*}$ & Balikesir & $29,86 \pm 0,22$ & $29,80 \pm 0,07$ & $21,78 \pm 0,20$ & 3,68E-03 & $3,86 \mathrm{E}-03$ \\
\hline $1 F^{*}$ & Bolu & $31,46 \pm 0,33$ & $30,97 \pm 0,25$ & $22,82 \pm 0,04$ & $0,25 E-03$ & 3,51E-03 \\
\hline $2 \mathrm{~F}^{*}$ & Cankiri & $30,93 \pm 0,03$ & $31,68 \pm 0,22$ & $23,55 \pm 0,38$ & $6,02 E-03$ & $3,58 \mathrm{E}-03$ \\
\hline $\mathrm{F} 2^{* *}$ & Marmara & $31,32 \pm 0,43$ & $31,89 \pm 0,19$ & $23,28 \pm 0,07$ & 3,81E-03 & 2,57E-03 \\
\hline $\mathrm{F} 12^{* *}$ & Balikesir & $31,71 \pm 0,09$ & $31,67 \pm 0,10$ & $22,54 \pm 0,02$ & 1,75E-03 & 1,79E-03 \\
\hline $\mathrm{F} 15^{\star *}$ & Sinop & $31,27 \pm 0,01$ & $32,07 \pm 0,009$ & $22,68 \pm 0,06$ & $2,59 \mathrm{E}-03$ & $1,49 \mathrm{E}-03$ \\
\hline $\mathrm{F} 16^{* *}$ & Konya & $31,09 \pm 0,18$ & $30,96 \pm 0,11$ & $22,99 \pm 0,16$ & 3,64E-03 & 3,97E-03 \\
\hline $\mathrm{F} 19^{* *}$ & Konya & $31,78 \pm 0,81$ & $31,84 \pm 0,32$ & $22,78 \pm 0,15$ & 1,95E-03 & 1,87E-03 \\
\hline
\end{tabular}

*means isolates belonging to $F$. graminearum, ${ }^{* *}$ means isolates belonging to $F$. culmorum 


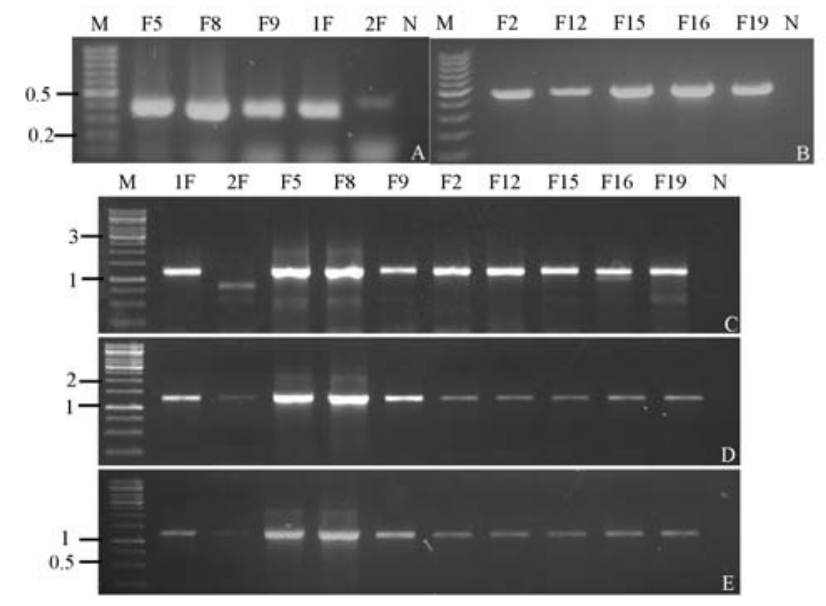

Figure 1. PCR amplification products A: of 332 bp with UBC85F/R primer in $F$. graminearum isolates B: of $472 \mathrm{bp}$ with OPT $18 \mathrm{~F} / \mathrm{R}$ primer in F. culmorum isolates C: of $1213 \mathrm{bp}$ long with ZEAF/R primer D: of 1551 bp with $B U T F / R$ primer and $E$ : of 1296 bp with FUSCF/R primer in all isolates. M: $1 \mathrm{~kb}$ DNA size marker (Thermo, USA), N: no template control

LightCycler $^{\circledR} 480$ II (Roche, Switzerland) system using SYBR Green qPCR kit (Thermo, USA). The qPCR experiments were conducted in a reaction volume of $16 \mu \mathrm{L}$ containing $1 \times$ SYBR Green mix, 4 pmol of each primer, cDNA amount corresponding to $500 \mathrm{ng}$ RNA. $\beta$-tubulin gene was amplified with TUBF/R primers $\left(5^{\prime}\right.$-gaagccattgatgttgttcgt- $3^{\prime} / 5^{\prime}$-tccgaccatgaagaagtgaag- $\left.3^{\prime}\right)$ as internal control. Cycling conditions were followed as; $95^{\circ} \mathrm{C}$ for $5 \mathrm{~min}, 40$ cycles of $95^{\circ} \mathrm{C}$ for $10 \mathrm{~s}, 55^{\circ} \mathrm{C}$ for $10 \mathrm{~s}, 72^{\circ} \mathrm{C}$ for $10 \mathrm{~s}$, and final extension at $72^{\circ} \mathrm{C}$ for $10 \mathrm{~min}$. Also, melting curve conditions were carried out to analyse the accuracy of real time PCR. Each experiment sets were replicated at least thrice. Standard curves were formed by cDNA series of 1:1/1:4/1:16/1:64 for each target genes and also for $\beta$-tubulin. According to the software, crossing point $(\Sigma \mathrm{Cp})$ values and target/reference ratios $(\Sigma \Delta \Delta \mathrm{CT})$ were calculated.

\section{Results}

According to species specific DNA marker amplifications, five isolates (F1, F2, F5, F8 and F9) produced a common band of 332 bp with UBC85 primer pair (Figure $1 \mathrm{~A}$ ). They were confirmed as F. graminearum. Gene fragment of $472 \mathrm{bp}$ in length were produced with OPT18 primers in remaining isolates (Figure $1 \mathrm{~B})$. It was revealed that they (F2, F12, F15, F16 and F19) belonged to F. culmorum.

PKS13 was amplified in all isolates as a band of 1213 bp long (Figure $1 \mathrm{C}$ ) except for $F$. graminearum
2F (850 bp). They yielded a common fragment of 1551 bp belonging to $F G 08079.1$ gene region (Figure $1 \mathrm{D})$. Amplification products of PKS10 of $1296 \mathrm{bp}$ in length were obtained from all isolates (Figure $1 \mathrm{E}$ ). It was demonstrated that three gene sequences were carried by $F$. graminearum and $F$. culmorum isolates.

Different expression levels of PKS13 and $F G 08079.1$ were detected in all isolates whereas no signal peaks were recorded for PKS10 gene (Table 1). Also, $\beta$-tubulin expression levels were calculated for all isolates (Table 1). $\Sigma \mathrm{Cp}$ values of FG08079.1 and $P K S 13$ were found as $29.86 \pm 0.22-32.18 \pm 1.14$ and $29.80 \pm 0.07-32.07 \pm 0.009$, respectively. Values were between $21.78 \pm 0.20-23.55 \pm 0.38$ for $\beta$-tubulin. After normalization, the highest gene expressions were recorded in $2 \mathrm{~F}$ isolate of $F$. graminearum for $F G 08079.1$ and F16 isolate of F. culmorum for $P K S 13$. While $\Sigma \Delta \Delta \mathrm{CT}$ values for $P K S 13$ were ranged from $1.79 \mathrm{E}-03$ to $3.97 \mathrm{E}-03$, the values calculated between $0.25 \mathrm{E}-03$ and 6.02E-03 for FG08079.1.

\section{Discussion}

Detection of phytopathogenic fungal species and their mycotoxins is crucial in development of plant disease control strategies. Conventional and molecular marker techniques are currently used in species-specific diagnostics and determination of mycotoxin types. Fusarium isolates (10) was identified by SCAR marker amplification and were determined as $F$. graminearum and $F$. culmorum.

Mycotoxin types and their quantity are important in the controlling of Fusarium diseases. To get information about genes associated with mycotoxin production is also essential. Since genes involved in biosynthesis of ZEN, BUT and FUS C are known (4). It is possible to predict possibility of the production of these toxins via expression analysis of the genes. PKS13, FG08079.1 and PKS10 genes were investigated at genomic and transcriptomic levels. Routine tests for trichothecene and zearealenone detection in cereals have been used. There is no any kit for butenolide and FUS C detection.

ZEN production can increase by high temperature as well as plant-pathogen interaction. But, this effect may vary depending on strain. The mycotoxin generally accumulates during growth phase and stays stabile on crops and their products. Our results showed that isolates included in the study produced ZEN mycotoxin under optimal culture conditions without any plant infection and/or stress factor. Moreover, F. graminearum $2 \mathrm{~F}$ isolate contained $P K S 13$ gene in a rather dif- 
ferent amplicon size (850 bp). This may suggest the presence of other variants of this gene as seen for trichothecene (14). Slight differentiation among gene expression profiles of isolates may support this argument. Nearly the same expression patterns were obtained among isolates even when the differences were statistically significant $(\mathrm{p}<0.05)$

The FG08079.1 is expressed during cell growth phase and in early stage of plant infection $(7,15)$. Here, $F G 08079.1$ was determined in all isolates under optimal culture conditions. It was noted an almost 24fold increase in BUT production in $1 \mathrm{~F}$ as opposed to $2 \mathrm{~F}$, isolates of $F$. graminearum. However, in isolates of $F$. culmorum, F2 was greater than F12-by only 2 fold. Expression levels of both PKS13 and FG08079.1 could provide information about aggressiveness of Fusarium isolates.

Despite the fact that PKS10 present in isolates of both fungal species, no expression of the gene was detected under optimal culture conditions. It was reported that FUS $\mathrm{C}$ was actively synthesized during growing mycelia, under high nitrogen concentrations or acidic conditions $(8,16)$. Therefore, the provided condition most likely was not suitable to induce the expression of PKS10. Investigation other genes involved in fusarin gene cluster could be useful in FUS $\mathrm{C}$ production analysis. The polyketide synthase, encoded by fus $A$, contain ten domains and four are characteristics of NRPS (nonribosomal peptide synthase) domain (16). To select the NPRS instead of $P K S 10$ could be useful for detection of fusarin production.

Relative quantification values of PKS13 and FG08079.1 were under "1", which was accepted as standard gene expression value for positive calibrator. These expression values were about $\times 10^{-3}$, smaller than the reference gene. These findings are indicative of low abundance of PKS13 and FG08079.1 associated with production of related mycotoxins. Moreover, these results obtained from optimal culture conditions would indirectly indicate mycotoxins levels produced by pathogens in non-inducing condition. Differentiation of isolates as mycotoxin producer or non-producer is carried out in a short time by using qPCR analysis. Our data showed that molecular approaches used in determination of mycotoxin type were efficient as much as conventional approaches. At the same time, it was seen that mycotoxin amount could be sensitively determined and compared by using real-time PCR.

Occurrence of various endotoxins (aflatoxin, T-2 toxin, DON, ZEN, and fumonisin) except BUT and FUS $\mathrm{C}$ have been reported by using conventional methods like HPLC and ELISA in Turkey $(17,18)$. Chemotyping studies of $F$. graminearum and $F$. culmorum isolates are focused on class B trichothecene detection $(14,19)$. But, there is no studies for ZEN, BUT and FUS C chemotyping in Turkey. Number of chemotyping investigation on these three mycotoxins has been also restricted worldwide when compared to class B chemotyping. To our knowledge, this is the first report to determine the potential of Fusarium isolates to produce ZEN, BUT and FUS C. Finding obtained from similar studies could contribute to evaluate of infection grade and to improve of disease control strategies.

\section{Acknowledgements}

The project was partially supported by Research Found of Istanbul University by project number 23655.

\section{References}

1. Steyn PS. Mycotoxins, general view, chemistry and structure. Toxicol Lett. 1995;82-83:843-851. DOI: 10.1016/03784274(95)03525-7

2. Bai G, Shaner G. Management and resistance in wheat and barley to fusarium headblight. Annu Rev Phytopathol. 2004;42:135161. DOI: 10.1146/annurev.phyto.42.040803.1 40340

3. Jurado M, Vázquez C, Patiño B, González-Jaén MT. PCR detection assays for the trichothecene-producing species Fusarium graminearum, Fusarium culmorum, Fusarium poae, Fusarium equiseti and Fusarium sporotrichioides. Syst Appl Microbiol. 2005;28:562-568. DOI: 10.1016/j.syapm. 2005.02.003

4. Desjardins AE, Proctor RH. Molecular biology of Fusarium toxins. Int J Food Microbiol. 2007;119:47-50. DOI: 10.1016/ j.ijfoodmicro.2007.07.024

5. Gaffoor I, Trail F. Characterization of two polyketide synthase genes involved in zearalenone biosynthesis in Gibberella zeae. Appl Environ Microbiol. 2006;72:1793-1799. DOI: 10. 1128/AEM.72.3.1793-1799.2006

6. Lysøe E, Klemsdal SS, Bone KR, Frandsen RJN, Johansen T, Thrane U, Giese H. The PKS4 gene of Fusarium graminearum is essential for zearalenone production. Appl Environ Microbiol. 2006;72:3924-3932. DOI:10.1128/AEM.00963-05

7. Harris LJ, Alexander NJ, Saparno A, Blackwell B, Mccormick SP, Desjardins AE, Robert LS, Tinker N, Hattori J, Piche C, Schernthaner J, Watson R, Ouellet T. A novel gene cluster in Fusarium graminearum contains a gene that contributes to butenolide biosynthesis. Fungal Genet Biol. 2007;44:293-306. DOI: 10.1016/j.fgb.2006.11.001

8. Niehaus E, Kleigrewe K, Wiemann P, Studt L, Sieber CMK, Connolly LR, Freitag M, Guldener U, Tudzynski B, Humpf H. Genetic manipulation of the Fusarium fujikuroi fusarin gene cluster yields insight into the complex regulation and fusarin biosynthetic pathway. J Chem Biol. 2013;20(8):1055- 
1066. DOI: 10.1016/j.chembiol.2013.07.004

9. Gaffoor I, Brown DW, Plattner R, Proctor RH, Qi W, Trail F. Functional analysis of the polyketide synthase genes in the filamentous fungus Gibberella zeae (anamorph Fusarium graminearum). Eukaryot Cell. 2005;4:1926-1933. DOI: 10. 1128/EC.4.11.1926-1933.2005

10. Niessen L. PCR-based diagnosis and quantification of mycotoxin producing fungi. Int J Food Microbiol. 2007;119:38-46. DOI: 10.1016/j.ijfoodmicro.2007.07.023

11. Bentley AR, Tunali B, Nicol JM, Burgess LW, Summerell, BA. A survey of Fusarium species associated with wheat and grass stem bases in Northern Turkey. Sydowia 2006;58:163177. URI: http://hdl.handle.net/10883/2538

12. Doyle JJ, Doyle JL. A rapid DNA isolation procedure for small quantities of fresh leaf tissue. Phytochem Bull. 1987;19:11-15.

13. Schilling AG, Möller EM, Geiger HH. Polymerase chain reaction-based assays for species-specific detection of Fusarium culmorum, F. graminearum and F. aveneceaum. Mol Plant Pathol. 1996;86(5):515-522. DOI: 10.1094/Phyto-86-515

14. Yöruk E, Albayrak G. Chemotyping of Fusarium graminearum and F. culmorum isolates from Turkey by PCR Assay. Mycopathologia 2012;173:53-61. DOI: 10.1007/s11046-011-
9462-2

15. Guldener U, Mannhaupt G, Munsterkotter M, Haase D, Oesterheld M, Stumpflen V, Mewes HW, Adam G. FGDB: A comprehensive fungal genome resource on the plant pathogen Fusarium graminearum. Nucleic Acids Res. 2006;34:456458. DOI: $10.1093 /$ nar/gkj026

16. Díaz-Sánchez V, Avalos J, Lýmón MC. Identification and regulation of fusA, the polyketide synthase gene responsible for fusarin production in Fusarium fujikuroi. Appl Environ Microbiol. 2012;78:7258-7266. DOI:10.1128/AEM.01552-12

17. Tunali B, Nicol J, Erol FY, Altýparmak G. Pathogenicity of Turkish crown and headscab isolates on stem bases on winter wheat under greenhouse conditions. Plant Pathol J. 2006;5(2):143-149. DOI: 10.3923/ppj.2006.143.149

18. Sahindokuyucu Kocasari F, Mor F, Oguz MN, Oguz FK. Occurrence of mycotoxins in feed samples in Burdur province, Turkey. Environ Monit Assess. 2013;185(4):9434949. DOI: 10.1007/s10661-012-2915-3

19. Mert-Turk F, Gencer G. Distribution of the 3-AcDON, 15AcDON, and NIV chemotypes of Fusarium culmorum in the North-West of Turkey. Plant Prot Sci. 2013;49(2):57-64. DOI: 10.3390/microorganisms1010162 